\title{
Neuromedin-K Receptor
}

National Cancer Institute

\section{Source}

National Cancer Institute. Neuromedin-K Receptor. NCI Thesaurus. Code C30057.

Neuromedin- $\mathrm{K}$ receptor (465 aa, $252 \mathrm{kDa}$ ) is encoded by the human TACR3 gene. This protein plays a role in tachykinin-dependent signal transduction. 